\title{
CULTURE OF SILENCE: SCRUTINISING THE UN'S “ZERO TOLERENCE” APPROACH TO SEXUAL EXPLOITATION AND ABUSE IN PEACE KEEPING OPERATIONS
}

\author{
Orhan ORHUN* \\ Adem PALABIYIK** \\ Ali Rıza SAVAŞ ${ }^{* * *}$
}

\begin{abstract}
The peacekeeping operations of the United Nations for bringing peace and stability, which have been accepted by the country and have great expectations from the people, sometimes fail to give the desired contribution but confront the people of the country, especially women and young girls. The habit of sexual abuse and exploitation, which is gained in almost every operation in which the United Nations intervenes and carries out a peacekeeping operation with another problem such as sexual abuse and exploitation, is now turning into a trust problem towards the United Nations. The complex post-war environment in which the United Nations intervened through peacekeepers is further complicated by this widespread and exposed problem posed by these forces. In this sense, it becomes as important as necessary to investigate the reasons why sexual abuse and exploitation are so widespread and permanent. The solutions that the United Nations tries to bring to this problem are not effective enough, and an effective method cannot be developed for the solution of this problem that has become permanent. Sexual abuse and exploitation, which is already a big problem in the legal context, is a complex problem that needs to be also solved in the illegal context. In this study, the reasons for the emergence of this problem, which has become unacceptable especially for women and young girls, have been discussed, and the efforts of the United Nations for a solution and the adequacy of this effort have been examined through examples.
\end{abstract}

Keywords: Culture of Silence, Peace, Sexual Abuse, United Nations, Zero Tolerance.

\section{SESSIZLLIK KÜLTÜRÜ: BM'NIN BARIŞ KORUMA OPERASYONLARINDA CINNSEL SÖMÜRÜ VE ISTTISMARA YÖNELIK ‘SIFIR TOLERANS' YAKLAŞIMINI İNCELEMEK}

\section{ÖZ}

Barış ve istikrarın tesisi için iç karışıklık yaşayan ülkelerin kabul ettikleri ve büyük umutlar besledikleri Birleşmiş Milletlerin barışı koruma hareketleri zaman zaman istenilen katkıyı verememenin yanında cinsel istismar ve sömürü gibi başka bir sorunla ülke halkını, özellikle kadın ve genç kızları, karşı karşıya bırakır. Birleşmiş Milletlerin müdahalede bulunduğu ve barışı koruma hareketlerini yürüttüğü hemen her operasyonda cinsel istismar ve sömürü konusunda kazanılan alışkanlık artık Birleşmiş Milletlere karşı bir güven problemi haline dönüşmektedir. Birleşmiş Milletlerin barış gücü askerleri aracıllğılyla müdahalede bulunduğu savaş sonrası karmaşı ortam yine bu güçlerin sebep olduğu ve yaygın bir şekilde gerçekleşip ifşa edilen bu sorunla daha da karışık bir hale gelmektedir. Bu bağlamda cinsel istismar ve sömürünün bu denli yaygın ve kalıcı olmasının nedenlerini araştırmak önemli olduğu kadar gerekli bir hale de gelmektedir. Birleşmiş Milletlerin bu soruna ilişkin getirmeye çalıştı̆̆ çözüm yolları yeteri kadar etkili olmayıp kalıcı hale gelen bu sorunun çözümüne dair etkili bir yöntem de geliştirilememektedir. Yasal zeminde halihazırda büyük bir problem olan cinsel istismar ve sömürü yasal olmayan bağlamda da çözüme ulaştırılması gereken karmaşık bir sorundur. Bu çalışmada özellikle kadın ve genç kızlar için kabul edilemez hale gelen bu sorunun ortaya çıkış nedenleri tartışılıp çözümü üzerine Birleşmiş Milletlerin ortaya koyduğu çaba ve bu çabanın yeterliliği örnekler üzerinden incelenmiştir.

Anahtar Kelimeler: Barış, Birleşmiş Milletler, Cinsel İstismar, Kültürü, Sıfır Tolerans.

\footnotetext{
${ }^{*}$ Dr. Araştırma Görevlisi, Batman Üniversitesi, Sosyoloji Bölümü, E-mail: orhanorhun06@ @otmail.com, ORCID Number: 0000-0002-3735-2865

** Doç. Dr., Bitlis Eren Üniversitesi, Sosyoloji Bölümü, E-mail: apalabiyik @beu.edu.tr, ORCID Number: 00000002-9209-9313

${ }^{* * * *}$ Dr. Öğr. Üyesi, Bitlis Eren Üniversitesi, İktisadi ve idari bilimler Fakültesi, Kamu Yönetimi Bölümü, E-mail: a.savas@ beu.edu.tr, Orcid Number: :0000-0003-0112-8033
} 


\section{Culture of Silence: Scrutinising the UN's “Zero Tolerence” Approach to Sexual \\ Exploitation and Abuse in Peace Keeping Operations}

Atıf: ORHUN, O., PALABIYIK, A., SAVAȘ, A. R. (2021). "Sessizlik Kültürü: BM'nin Barış Koruma Operasyonlarında Cinsel Sömürü ve İstismara Yönelik 'Sıfır Tolerans’ Yaklaşımını İncelemek”, İMGELEM, 5 (9): 211-227.

Citation: ORHUN, O, PALABIYIK, A., SAVAŞ, A. R. (2021). “Culture of Silence: Scrutinising The UN's “Zero Tolerence" Approach to Sexual Exploitation and Abuse in Peace Keeping Operations”, IMGELEM, 5 (9): 211 227.

Başvuru / Received: 10 Ağustos /August 2021.

Kabul / Accepted: 8 Aralık / December 2021.

Derleme Makale/ Review Article.

\section{INTRODUCTION}

"Bombs and missiles kill men and women indiscriminately, but other aspects of war affect women and girls disproportionately."

(Ashford - Huet 2004: 431).

The peacekeeping operations (PKO) of the United Nations (UN) have greatly contributed to bringing peace and stability to countries emerging from war (General Assembly 2005: 1) The disclosure of the widespread occurrences of sexual abuse and exploitation (SEA) in UN PKOs, perpetrated by UN peacekeepers, has clouded the UN's exemplary record (General Assembly 2005) SEA does not only damage the image of a PKO, it mars its credibility (General Assembly 2005: 9) The persistence of SEA in virtually every PKO illustrates that the measures in place are manifestly inadequate (General Assembly 2005: 1).

This article scrutinises reasons for the persistence of SEA in PKOs. The article focuses especially on an appraisal of the UN's (legislative) responses. At the centre of the analysis is the Secretary General's Bulletin 2003 (SGB 2003). The article argues the premise that a purely legal solution to the persistence of SEA in PKOs cannot offer viable solutions. Instead, the problem requires solutions that recognise external factors of the legal frameworks. This was recognised by the 2006 "Resolution on the Involvement of U.N. Forces in Sexual Abuse in Liberia and Haiti", issued by the European Parliament (European Parliament Resolution on the Involvement-EPRI 2006). The resolution pointed to the "culture of silence" in the peacekeeping culture (EPRI 2006: 1). Accordingly, the article's methodological approach includes elements of socio-legal- and feminist analysis. The subsequent proposals seek an amalgamation of the different elements of the analysis in order to provide meaningful recommendations.

The article restricts its scope to SEA as a human rights violation. Moreover, it is important to acknowledge that SEA does not only affect women and young girls. The media 
has played an important role in shedding light on male victims (Delva 2011). Nevertheless, the focus of this study is predominantly limited to SEA perpetrated against women and young girls.

The aim of the article is to scrutinise the multifaceted factors which facilitate and perpetuate SEA in PKOs. The research statement questions how can the UN's zero tolerance policy contribute more effectively to put an end to the persistence of SEA in PKOs. Aware that resolving the problem of SEA in PKOs requires the combined effort of the UN, its bodies, and the Member States (General Assembly 2005: 2) this article solely focuses on the role of the UN. Therefore, the scope excludes a profound discussion of the responsibility of troop-contributing states and host states. This article argues that SEA in PKO is a complex problem within the legal context as well as outside of it. Therefore, the main sub-question addressed in the analysis is why does, despite the UN's zero tolerance policy, SEA continue to persist.

A thorough analysis of the persistence of SEA in PKOs requires defining the concept of SEA and placing it in a historical context of gender based crimes in international law. In addition, this part includes a general introduction to PKOs. Thereafter, the article outlines the legal framework of SEA concerning peacekeeping forces. It has been looked into legislative responses here. The third part analyses the main research question; the persistence of SEA in PKOs. A case study on SEA in the UN Stabilisation Mission in Haiti (MINUSTAH), preceding this analysis, illustrates the associated difficulties. The last part of the article seeks to make viable and relevant recommendations to put an end to SEA in PKOs. Subsequently, the main findings of the article are concluded.

\section{International Regulation of Sexual Exploitation and Abuse}

Sexual exploitation and sexual abuse are two separate concepts. SEA is defined as "any actual or attempted abuse of a position of vulnerability, differential power, or trust for sexual purposes, including, but not limited to, profiting monetarily, socially or politically from the sexual exploitation of another" (The Secretary-General 2003: 1-3). Sexual abuse constitutes an "actual or threatened physical intrusion of a sexual nature, whether by force or under unequal or coercive conditions" (The Secretary-General 2003: 1-3). These definitions of SEA, found in the SGB 2003, omit any reference to the age of the victims and render consent immaterial (Ndulo 2009: 146). The rationale for this stems from acknowledging the unequal power relations between the peacekeepers and the local population and the protective nature of the job (Ndulo 2009). Consequently, peacekeepers are held to a higher standard than any ordinary person (Ndulo 2009). The jurisprudence of the International Criminal Tribunal for the former 


\section{Culture of Silence: Scrutinising the UN's “Zero Tolerence” Approach to Sexual Exploitation and Abuse in Peace Keeping Operations}

Yugoslavia (ICTY) and the International Criminal Tribunal for Rwanda (ICTR) constitute an important shift to rectifying international law's initial apathy towards gender-based and sexual crimes (Ndulo 2009: 127). In the Tadic case, sexual violence was formally recognised as an international crime, and the Akayesu case concluded that rape could constitute genocide - given that the specific intent to destroy a particular group in whole or in part could be established (Ndulo 2009: 134). By codifying forms of sexual assaults and sexual violence as crimes against humanity, the Rome Statute achieved another major stride (Ndulo 2009). Priory crimes of that nature were perceived as an unfortunate but inevitable consequence of war (Ndulo 2009: 131). Women were regarded as spoils of war.

PKOs have emerged in the decolonisation process, emanating from the need to stop hostilities and prevent conflicts from developing into broader conflicts (Ndulo 2009: 128). They are designed to work out a political solution and to address the underlying causes of a conflict (Ndulo 2009). The dramatic increase in PKOs after the end of the Cold War has led to the emergence of a major problem: SEA committed by UN peacekeepers on local populations in the context of the mission (Ndulo 2009: 129). The first allegations emerged in November 2001 (Ndulo 2009: 141), although many scholars argue that the first warning signs appeared in the early 1990s (Alexandra 2011: 369). These early signs have concerned a rise in prostitution and human trafficking in Cambodia as a result of the UN peacekeepers' presence there (Alexandra, 2011). Accusations have evolved around sex trafficking, soliciting prostitutes, forced prostitution of children, sexual relations with minors, and fathering and leaving behind babies (Ndulo 2009: 129).

Since then, it has been found that SEA is not confined to peacekeepers from a particular region (Ndulo 2009: 130). It is a widespread phenomenon including military and civilian personnel at all levels of the UN, meaning that high-level UN officials are not excluded from the charges (Ndulo 2009; Defeis 2008: 187).

\section{The Legal Framework Concerning SEA for Peacekeeping Forces}

A UN PKO is established by a Security Council resolution and is, thus, a subsidiary organ of the UN. As a subsidiary organ, a PKO enjoys the UN's status, privileges, and immunities stipulated in Article 105 of the Charter and the 1946 Convention on the Privileges 
and Immunities of the UN (CPIUN) (Murphy 2006: 533). The legal framework for UN forces usually includes a Security Council Resolution, a Status-of-Forces Agreement (SOFA), a Memorandum of Understanding (MOD), and the Force Regulations issued by the SecretaryGeneral (Murphy 2006). Pursuant to the UN, the military and police personnel are "first and foremost members of their own national service and are then seconded to work with the UN" (Vezina 2012: 449). A MOD is formed between the UN and the troop-contributing Member State in service to the UN. The MOD details conditions of deployment, resources provided, and response times (Vezina 2012: 450). In 2007 the UN developed a Model MOD, which requires troop-contributing countries to inform the UN about investigations and sanctions against a peacekeeper or an alleged perpetrator of SEA (Simić 2010: 192): It furthermore enables the UN to support an investigation to conduct its own investigation and to follow up (Simić 2010). The SOFA is formed between the UN and the host State. Pursuant to a clause in the SOFA, "basic privileges and immunities of a [UN] peacekeeping operation flow from the" CPIUN (Vezina 2012: 450).

According to the CPIUN, a Member State is obliged to waive immunity if it impedes the course of justice. Until today, this provision has not been invoked (Vezina 2012). It is important to note that this refers to functional immunity. Thus, the immunities do not apply for acts outside of his official capacity (Vezina 2012). This matter has been further complicated by the SOFA, which usually provides that offenders are subject to the exclusive jurisdiction of their home state. As a consequence, a host state cannot exercise jurisdiction (Vezina 2012: 451).

The 1979 Convention on the Elimination of All Forms of Discrimination against Women (CEDAW) has provided women with a certain degree of protection. Yet, women remain vulnerable to SEA, torture, slavery, rape, and other crimes against humanity (Murphy 2006: 534). The 2000 UN Security Council Resolution 1325 on Women, Peace and Security focused on rape and other forms of sexual abuse in armed conflicts and called upon the full implementation of international humanitarian and human rights law to protect the rights of women and girls in conflict and post-conflict situations (Ndulo 2009: 132). Furthermore, the resolution mandated the peacekeeping commanders' recognition of the differential impact of their actions on men and women; gender-sensitive training; as well as an expansion of the role of women in the field-based operations (Defeis 2008: 193).

In 2003 the SGB 2003 was promulgated as a set of rules that governs disciplinary matters relating to SEA in PKOs and provides sanctions for violations (Ndulo 2009: 147). 


\section{Culture of Silence: Scrutinising the UN's “Zero Tolerence” Approach to Sexual Exploitation and Abuse in Peace Keeping Operations}

Pursuant to the SGB, "solicitation of prostitutes, engaging in sex with minors under age 18, the withholding of goods or services until demands for sex are met, and the exchange of money and other items for sex or sexual favors" are prohibited (Alexandra 2011: 370). In other words, the SGB 2003 does not only prohibit child prostitution; it forbids prostitution in general (Kanetake 2010: 201). This general prohibition is important and to be contrasted with other human rights documents. CEDAW and the 1989 Convention on the Rights of the Child both envisage the prevention and suppression of exploitation of the prostitution of women or children, not (child) prostitution itself (Kanetake 2010). The scope of application of the SGB 2003 covers all UN staff (Ndulo 2009: 147). It is important to note that uniformed personnel falls under the jurisdiction of their governments. Thus, the Bulletin is not legally binding on them, and the UN cannot subject them to their disciplinary procedures (Ndulo 2009: 149). In this case, the Bulletin constitutes a code of conduct.

In the 2004 'comprehensive strategy to eliminate future sexual exploitation and abuse in United Nations peacekeeping operations' (Zeid report), the Secretary-General acknowledged a manifest inadequacy of the procedures in place (Defeis 2008: 188). The Zeid report constitutes the "first comprehensive analysis of the problem of" SEA "by United Nations peacekeeping personnel" and is a result of the collaboration between Kofi Anan and Prince Zeid Ra'ad AlHussein, Permanent Representative of Jordan (General Assembly 2005: 2). The Zeid Report has resulted in the adoption of a two-year plan of action, aiming to address the problem of SEA in UN peacekeeping missions (Defeis 2008: 194). In addition to these UN-based responses, it is important to note that two publications regulate peacekeeper's conduct: both "Ten Rules: Code of Personal Conduct for Blue Helmets" and "We Are United Nations Peacekeepers" explicitly contain prohibitions of sexual exploitation (Defeis 2008).

Investigating allegations of offences relating to SEA are dealt with by the UN's Office of Internal Oversight Services (OIOS). This, however, excludes allegations against members of the national contingents. The OIOS is known to suffer from insufficient resources, as acknowledged by the Secretary-General (Defeis 2008: 197). As a consequence, it has a backlog of serious misconduct that has not yet been investigated (Defeis 2008). The Conduct and Discipline Teams (CDTs) constitute a forum where sexual exploitation complaints can be received and assessed. Allegations concerning discrimination, sexual harassment and abusive behaviour, are subject to either the Special Investigation Unit, the Military or UN police or adhoc panels. 


\section{Mınustah - A Case Study}

On the $1^{\text {st }}$ of June 2004, Security Council Resolution 1542 creating MINUSTAH was passed in response to an armed conflict in Haiti constituting a threat to international peace and security (Vezina 2012: 434). In 2008 the media reported on 114 UN peacekeepers facing SEA charges (Tamil Guardian 2008). Reference was made to Amnesty International reporting as early as in 2001 on a "marked rise in allegations of rape by police, army and navy personnel" (Tamil Guardian 2008). The subsequent repatriation of the 114 peacekeepers of Sri Lankan origin has constituted one of the largest single withdrawals of soldiers from a UN PKO. The OIOS stated that it was to assist in the pending legal proceedings that were initiated by the Sri Lankan Government to ensure accountability of the peacekeepers (Tamil Guardian 2008). Furthermore, the OIOS confirmed the frequency and widespread nature of the acts of SEA, referring to acts of SEA against children involving exchanging small amounts of money and food or mobile phones in exchange for sex (Tamil Guardian 2008). Trading sex for food or money or jobs and acts of rape disguised as prostitution have been commonplace in other PKOs (Defeis 2008: 188). In 2011, the media reported on a mobile phone video depicting the assault of a young Haitian man by UN peacekeepers (MacFarquhar 2011).

While these two examples constitute the two most widely reported examples of SEA in MINUSTAH, along with recent reports on the sentencing of two Pakistani peacekeepers for rape (BBC 2012), the widespread nature of SEA was addressed by the Security Council (Security Council 2011) The acknowledgement and condemnation included reference to "grave violations against children" and the "widespread rape and other sexual abuse of women and girls" (Security Council 2011). Indeed, numerous reports surfaced, describing how peacekeeping troops offer girls between the ages of thirteen to fifteen a small amount of money (\$1-\$3) in exchange for performing sexual acts (Vezina 2012: 439). Younger girls between the ages of ten and fourteen years have been subjected to sexual assault by UN peacekeepers (Vezina 2012).

In the case of the 114 repatriated Sri Lankan peacekeepers, the OIOS recommended that the men should be charged with rape because the victims were under the age of eighteen (Vezina 2012: 442). The Sri Lankan government later promised the UN to "look into" the allegations that "its soldiers paid for sex, in some cases with underage girls" (Simić 2010: 191). Five Uruguayan peacekeepers identified in the mobile phone video were returned to Uruguay to face prosecution by either the Uruguayan government or military tribunal (Vezina 2012: 442). It 


\section{Culture of Silence: Scrutinising the UN's “Zero Tolerence” Approach to Sexual Exploitation and Abuse in Peace Keeping Operations}

was, however, reported that these men were later released when authorities failed to obtain the testimony of the Haitian victim. According to the associated press, the young Haitian man stated that he had not been asked to testify (Vezina 2012: 443). Both cases demonstrate the limited power of the UN to discipline the offending tops when the peacekeepers are returned to their home countries to face prosecution (Vezina 2012).

\section{Why does SEA continue to persist?}

In the aftermath of the issuance of SGB 2003, a concerted effort by the UN found that the overwhelming majority of SEA allegations were addressed against the Department of Peacekeeping Operations (DPKOs) (Alexandra 2011: 370). From the $1^{\text {st }}$ of January 2004 until the $9^{\text {th }}$ of December 2005, 278 investigations against peacekeeping personnel resulted in the repatriation of 122 military personnel on disciplinary grounds and 16 members of formed police units and resulted in the dismissal of 16 civilians (Murphy 2006: 532). In 2005 the aforementioned allegations peaked, amounting to the total number of 373 (Alexandra 2011: 370). In other words, SEA remains a major concern (Alexandra 2011).

It is important to note that PKOs do not include a homogenous group of personnel. Operations include a civilian, military, and police component (General Assembly 2005: 10). In these three broad components, five categories of personnel can be identified. These include members of national military contingents (blue helmets), civilian police, civilian staff, UN volunteers, and military observers (Murphy 2006: 533). As a consequence of the potpourri of personnel, each category is subject to a distinct legal status and is governed by different rules and disciplinary procedures ((Ndulo 2009: 147; General Assembly 2005: 10). Pursuant to the status of forces agreement, troop-contributing countries are responsible for the conduct and discipline of their own troops in accordance with national law and military regulations (Ndulo 2009: 147).

A short depiction of the different categories of a PKO helps in understanding "the extensive mosaic of provisions" dealing with SEA which have been "drafted at varying points in time and with varying degrees of legal force" (General Assembly 2005: 12). The CPIUN stipulates that UN personnel enjoy functional immunity from criminal prosecution by national authorities, unless this immunity is waived by the Secretary-General (Defeis 2008: 200). Furthermore, UN staff is subject to standards of conduct, which are set out in the Staff Regulations and Rules as well as in subordinate administrative issuances (General Assembly, 
2005: 10). Enforcement is achieved under the Organization's disciplinary procedures (General Assembly 2005). Immunity is extended to UN volunteers through recent SOFAs. Their conduct is governed by their rules of conduct and disciplinary procedure (General Assembly 2005: 11). Individual consultants and contractors are subject to local law and are governed by the Organisation's standard conditions of contract (General Assembly 2005). The status and privileges and the immunities of the CPIUN are extended to civilian police and military observers (General Assembly 2005). They, moreover, sign other documents, such as an "undertaking" in which they declare themselves bound by mission standards and other procedures, policies, directives and issuances, as well as mission-specific directives and guidelines (General Assembly 2005).

Military members of national contingents benefit from the privileges and immunities set out in the SOFA (General Assembly 2005). These agreements identify the troop-contributing country as having criminal and disciplinary jurisdiction over military members of the contingents (General Assembly 2005). The Secretary-General can order the repatriation of any military member of the contingent, found culpable of serious misconduct in an investigation (General Assembly 2005). Prohibitions of SEA stipulated in the 2003 SGB have been included in mission-specific guidelines (General Assembly 2005: 12). It is important to note that as guidelines, they only present a model that does not need to be strictly adhered to (General Assembly 2005).

One of the most important shortcomings is that the SBG 2003 is not applicable to all categories (General Assembly 2005: 10). This unsatisfactory fact has been addressed by the Zeid Report, but the issue continues to persist (Murphy 2006: 534). As a result, only UN staff members are "unquestionably bound" by the SGB 2003 (General Assembly 2005: 12). Military observers and civilian police are bound by directives that incorporate a summary of the prohibitions (General Assembly 2005). Military members of contingents, on the contrary, can only be subjected to binding rules with the agreement of and action by the respective troopcontributing country (General Assembly 2005). Disciplining SEA in PKOs is highly uneven and troop-contributing countries have been found to have a poor record of holding perpetrators accountable (Defeis 2008: 192, 207). This contributes to a culture of impunity. In addition, the belief that peacekeepers can get away with SEA considerably contributes to the culture of impunity (Ndulo 2009: 144). This has often been linked to the remote location of PKOs. This is likely to lead to a breakdown of accepted standards of sexual conduct and increases the likelihood of misconduct going unpunished (Alexandra 2011:373). 


\section{Culture of Silence: Scrutinising the UN's “Zero Tolerence” Approach to Sexual Exploitation and Abuse in Peace Keeping Operations}

Despite peacekeepers not being a homogenous group, the overwhelming majority of peacekeepers are men (Defeis 2008: 191). Consequently, the existence of a "hyper-masculine culture" is likely to encourage SEA (Defeis 2008). This masculine culture has several repercussions. First, instances of SEA are at the risk of being dismissed as a "boys will be boys" problem - as previously done by an UN official (Defeis 2008). Secondly, masculine culture, as found in police departments, militaries, and fraternities, has been found to allow for a "wall of silence" and to stigmatise "whistle-blowers" (Defeis 2008: 192). Therefore, instances of SEA may go unreported (Defeis 2008).

Women are underrepresented in the role of female peacekeepers. It can be argued that the underrepresentation and absence of women in PKOs undermine the legitimacy of such missions. Charlesworth and Slaughter make this observation about international organisations (Charlesworth \& Slaughter 1995: 79). They argue that not only the relevance but more importantly the legitimacy, of international institutions are undermined by "their exclusion of over half the world's population - women - from their process" (Charlesworth \& Slaughter 1995: 79-80). As a consequence, the nature of the institution can only be seen as a "veiled representation and projection of a masculine which takes itself as the unquestioned norm" (Charlesworth \& Slaughter 1995: 79-80). This underrepresentation is particularly striking when considering the UN's institutional commitment to the equality of men and women through the preamble of its Charter (Charter of the United Nations 1945).

Post-conflict environments are characterised by power differentials between peacekeepers and the local population (Ndulo 2009: 130). This is perpetuated by the absence of the rule of law, corruption, weak judicial systems, and collapsed economies (Ndulo 2009). These factors lead to an increased vulnerability of local populations to SEA (Ndulo 2009). Economic conditions, in particular poverty and high rates of unemployment, are similarly contributing factors to the pervasiveness of SEA (Ndulo 2009: 144). Through poor economic conditions and the extreme economic disparity between the local population and peacekeepers, prostitution becomes a source of income for women and girls ((Ndulo 2009; Alexandra 2011: 373). This goes even so far as regarding the exchange of food or money for sexual favours as an act of altruism (Alexandra 2011: 374).

There is much contention as to the question of the agency of women involved in prostitution. Alexandra writes that male, as well as female peacekeepers, regarded local women as "active agents in pursuit of sexual relationships with male peacekeepers" (Alexandra 2011). 
Ndulo argues that the agency of older women should not be disregarded (Ndulo 2009: 144). In a number of cases, older women and girls are not forced into prostitution but willingly engage in it (Ndulo 2009). This can have detrimental repercussions for the UN investigations seeking to verify the accusations of SEA. A number of girls in Bunia were not cooperating in the investigations out of fear that an investigation confirming the allegations would "eliminate what they described as their only source of income" (Ndulo 2009). In other words, the economic incentive to report prostitution is lacking (General Assembly 2005: 10). The debate on agency has to be seen in a context where prostitution is perceived as the only source of income, or rather as the only means of survival (Ndulo 2009: 144). Spencer argues along the same lines by emphasising that the exchange of sex or sexual acts is misunderstood as an expression of agency (Spencer 2004: 171). This form of agency stemming from a sheer sense of survival cannot serve as an excuse for the deeds of the peacekeepers, or worse, conceal them as acts of altruism (Ndulo 2009: 144).

A further factor to be considered is the association of masculinity with sexuality (Alexandra 2011: 373). In the past sexual interactions between the local women and peacekeepers were encouraged on the basis of men's innate sexual needs and, thus, the construction of masculinity which privileges sexual needs (Alexandra 2011). This emanated from the belief that "it would improve the work-related function of stressed (male) peacekeepers" (Alexandra 2011). The appropriateness of contributing war-trained soldiers as peacekeepers has been questioned. Thereby, the enculturation into militarised masculinities has been identified as one of the root causes for the persistence of SEA (Alexandra 2011: 371). In addition, it has been argued that the organisations structure of the military results in a misogynist version of masculinity that facilitates SEA (Alexandra 2011). While findings that SEA is mainly committed by military personnel corroborates this analysis, it is important to resist the temptation of an overgeneralisation, as this would perpetuate "a unitary idea of male soldiers" that unanimously engage in SEA (Alexandra 2011).

\section{Recommendations}

The preceding analysis of the causes of SEA has demonstrated a multifaceted problem by explaining different underlying causes. Turning to the main research question, this section of the essay addresses how the UN's zero-tolerance policy can contribute more effectively to end the persistence of SEA in PKOs? The main challenge that will need to be met is ending 


\section{Culture of Silence: Scrutinising the UN's “Zero Tolerence” Approach to Sexual Exploitation and Abuse in Peace Keeping Operations}

impunity and prosecuting the perpetrators. The foregoing analysis and case study have pointed out the difficulties associated with this. Here, it was shown that the UN could only partially be responsible for putting a stop to the persistence of SEA in peacekeeping operations (Kanetake 2010: 201). The responsibility of the troop-contributing country and the host country are equally important in implementing the UN's zero tolerance policy to SEA. At the same time, it has been acknowledged that not all victims endorse the strategy and, therefore, might not cooperate (Kanetake 2010). The UN lacks the legal authority to prosecute the perpetrators and - at most - can repatriate a peacekeeper to their country of origin. That is to say that it, similarly, cannot ensure the prosecution of the peacekeeper in their country of origin (Murphy 2006: 532).

One necessary proposal is the enforcement of the SGB 2003 for all categories of a PKO (Murphy 2006: 542). While the standards of the SGB 2003 have been incorporated into various legal documents, standards of conduct for members of military contingents continue to present an area of concern (Defeis 2008: 196). Rules of conduct often only reflect guidelines in troopcontributing countries and, consequently, may not be regarded as legally binding (Defeis 2008). Detailed prohibitions on SEA need to have the status of binding rules and cannot only be guidelines (General Assembly 2005: 12). A further step would be the elimination of the phrase in the SOFA, giving the troop-contributing country exclusive exercise jurisdiction (Spencer 2004: 177). As pointed out by the case study on Haiti, perpetrators often go unpunished or only receive light sentences. Similarly, a viable recommendation would be the establishment of a central monitoring system concerned with tracking the process and outcome of home state prosecution (Murphy 2006: 542).

In response to the immunity of UN personnel from criminal prosecution pursuant to the CPIUN, the creation of a new international convention, which does not undermine the UN's immunity but facilitates waiving the immunity of individuals, has been proposed (Defeis 2008: 200). This proposed draft Convention is, however, problematic in a number of aspects. One of the most controversial omissions is that the exchange of food or money for sex does not appear to be a crime within the meaning of the proposed Convention (Defeis 2008: 201). This stands in contrast to the SGB 2003, which stipulates that such an act would violate the set out standards (Defeis 2008). The recognition that prostitution in the peacekeeping context and is inherently coercive in nature is particularly important (Defeis 2008: 205). Prostitution in this context has to be demarcated from 'voluntary prostitution', which may be legal under a state's national law (Defeis 2008). 
Concerns about establishing a better functioning investigative mechanism has resulted in proposing the establishment of an independent and permanent investigative mechanism within the DPKO (Defeis 2008: 197). Such a mechanism, dealing with both severe and less severe complaints of SEA within one institution could, furthermore, lead to a stronger mechanism. An independent and permanent mechanism could build up a strong area of expertise that would ensure more effective and timely functioning. Furthermore, the need to improve the investigation itself by including on-site courts-martial as well as DNA and fingerprinting technology has previously been addressed (Defeis 2008). The wearing of uniforms is a point of contention when it comes to investigative measures. It has been held that victims might be more prone to approach a female peacekeeper than a male one (Simić 2010: 195). Yet, Norwegian female peacekeepers reported that the individuals generally react to the authority exuded by the uniform, not to their sex (Simić 2010). As a consequence, the investigative procedures should be careful to incorporate this experience.

In the same manner, as the purpose of the previous analysis was to carve out that solutions do not purely lie in the law, it is therefore important to emphasise the prevention of SEA and to build an environment that discourages SEA. The focus on prevention should go hand in hand with in field-level implementation of reporting monitoring and improving the investigative structures (Spencer 2004: 172). Similarly, reporting mechanisms should be made more accessible and more aware of to the local population (Spencer 2004: 176). Since a number of women do not report because they fear negative repercussions, the confidentiality of an investigation should be ensured (Spencer 2004: 177).

Simple preventive measures could include practicable ideas such as the wearing of uniforms at all times, telephone hotlines and of-limits areas (Defeis 2008: 198). Despite an increase in female peacekeepers in recent years, there is unanimous recognition of the need for greater participation of female peacekeepers (Defeis 2008: 199). It is argued that increased participation of female peacekeepers, particularly at the senior level, would discourage the enculturation into military masculinities. This would result in an environment that discourages SEA (Defeis 2008). At the same time, UN officials have noted that child- and female victims have been more comfortable dealing with a female officer due to the culturally and emotionally sensitive nature of SEA (Defeis 2008). A notable example was the deployment of an all-women team of UN peacekeepers by India in Liberia (Defeis 2008). While the definite effects of increased participation of female peacekeepers cannot be predicted, it can be argued that only 


\section{Culture of Silence: Scrutinising the UN's “Zero Tolerence” Approach to Sexual Exploitation and Abuse in Peace Keeping Operations}

the inclusion of women in the peacekeeping process can ensure the embracement of women's experiences and close the gendered lacunae (Charlesworth \& Slaughter 1995: 83).

The increased participation of female peacekeepers has, at the same time, been a point of contention. The implication that female peacekeepers have a pacifying presence and reduce aggressiveness and hypermasculinity is visible from a statement by the DPKO (Simić 2010: 189-190). The assumptions harboured in this argument imply that women are more peaceful than men and that their presence potentially decreases SEA by their male colleagues (Simić 2010: 190). Yet, observations on the Indian all-female police unit in Liberia supported the argument that instead of changing the military hypermasculine environment, women tend to fit in with it (Simić 2010: 194). Similarly, a 2008 report found that female peacekeepers are not more willing to break the culture of silence by reporting male colleagues (Simić 2010: 195).

The increased participation of female peacekeepers could, however, counteract the marginalisation of women in PKOs. Puechguirbal argues that women are not seen as actors or agents in post-conflict situations (Puechguirbal 2010: 172). Women are solely defined along the lines of civilians, victims, in association to children, or described as vulnerable (Puechguirbal 2010: 172). Increasing the participation of female peacekeepers could, thus, shift the focus to seeing women as social subjects and give them a role at the peace negotiating table (Puechguirbal 2010: 177). Similarly, it would address the imputed correlation between the "failure to promote women to high level in the UN peacebuilding system and a lack of advocacy for women's rights in peacebuilding" (Puechguirbal 2010: 182).

Lastly, poor economic conditions have been identified as a major underlying factor, often resulting in the complex problem of prostitution. It would be pivotal to promote sustainable economic development so as to reduce the vulnerability of the local population to SEA by peacekeepers (Ndulo 2009: 145). This could be counteracted by the promotion of selfsufficiency. In other words, women should be provided with "jobs, loans to start small businesses, education" and skills training so as to eliminate their dependency on humanitarian aid (Spencer 2004: 173).

\section{CONCLUSION}

The widespread occurrence of SEA in post-conflict situations is influenced by a variety of legal, social, economic, and gendered factors. The heterogeneous group of UN peacekeeping personnel is subject to a complex mosaic of provisions, applicable with varying degrees of legal 
force. The consequently uneven disciplining of peacekeepers results in a culture of impunity, aggravated by different social factors. The quasi absence of female peacekeepers has been addressed, as well as the problem of prostitution being a direct consequence of poor economic conditions.

SEA is a problem requiring the action of several actors. If evidence of wrongdoing confirms conduct of SEA in a UN PKO, the UN lacks the legal authority to prosecute the perpetrators. While the UN can repatriate a peacekeeper to his country of origin, the prosecution cannot be ensured. The persistence of the problem indicates that SEA is either not perceived as wrong by the peacekeepers committing these acts or that they simply do not fear serious repercussions for their actions. As a consequence, it is pivotal to address the peacekeeper's accountability and to put a stop to impunity. This should involve prosecution and appropriate punishment. An anticipated consequence of appropriate punishment would be the deterrence of other peacekeepers to commit similar crimes in the future (Ndulo 2009: 145). This proposal should go hand in hand with improved investigative and monitoring mechanisms. It is equally important to address the underlying factors that facilitate situations in which SEA occurs and to implement preventive measures. In this context, the recommendations have critically questioned the actual effects of increased participation in female peacekeepers and have recommended the promotion of self-sufficiency to counteract the detrimental effects of poor economic conditions. 


\section{Culture of Silence: Scrutinising the UN's “Zero Tolerence” Approach to Sexual Exploitation and Abuse in Peace Keeping Operations}

\section{REFERENCES}

Alexandra, K. (2011). Peacekeepers' Privilege and Sexual Abuse in Post-Conflict Populations, Peace Review: A Journal of Social Justice, 23(3), 369-376.

Ashford \& Huet-Vaughn in Hynes, H. (2004). On The Battlefield of Women's Bodies: An Overview of The Harm of War to Women, Women's Studies International Forum, (27), 431-445.

BBC (2021, 13 March), Two Pakistani UN Soldiers Jailed for Raping Haitian Boy, http://www.bbc.co.uk/news/world-latin-america-17351144 (Access: 19 May 2020).

Charlesworth, H., Slaughter, A. M. (1995). The Gender of International Institutions, American Society of International Law Proceedings, (89), 79-84.

Charter of the United Nations. (1945). Charter of the United Nations and Statute of the International Court of Justice. https://treaties.un.org/doc/publication/ctc/uncharter.pdf (Access: 9 May 2020).

Defeis, E. (2008). U.N. Peacekeepers and Sexual Abuse and Exploitation: An End to Impunity, Washington University Global Studies Law Review, 7(2), 185-214.

Delva, J. (2011, 9 May). U.N. Haiti peacekeepers face outcry over alleged rape. http://www.huffingtonpost.com/2011/09/05/un-haiti-peacekeepers-f_n_949195.html (Access: 13 May 2020).

European Parliament Resolution on the Involvement of U.N. Forces in Sexual Abuse in Liberia and Haiti. Eur. Parl. Doc. P6_TA (2006)0606.

General Assembly, Comprehensive review of the whole question of peacekeeping operations in all their aspects, A/59/710, 24 March 2005.

Kanetake, M. (2010). Whose Zero Tolerance Counts? Reassessing a Zero Tolerance Policy against Sexual Exploitation and Abuse by UN Peacekeepers, International Peacekeeping, 17(2), 200-214.

Mac Farquhar, N. (2011, 7 September). Peacekeepers' Sex Scandals Lingers, On Screen and Off. http://www.nytimes.com/2011/09/08/world/08nations.html?pagewanted =all\&_r=0 (Access: 19 May 2020).

Murphy, R. (2006). An Assessment of UN Efforts to Address Sexual Misconduct by Peacekeeping Personnel, International Peacekeeping, 13(4), 531-546.

Ndulo, M. (2009). The United Nations Responses to the Sexual Abuse and Exploitation of Women and Girls by Peacekeepers during Peacekeeping Missions, Berkeley Journal of International Law, 27(1), 127-161.

OHCHR. (2020, 25 May). 1979 Convention on the Elimination of All Forms of Discrimination against Women. https://www.ohchr.org/en/professionalinterest/pages/cedaw.aspx

Puechguirbal, N. (2010). Discourses on Gender, Patriarchy and Resolution 1325: A Textual Analysis of UN Documents, International Peacekeeping, 17(2), 172-187.

Security Council, Security Council Authorizes One-Year Extension of Haiti Stabilization Force, Also Approves Withdrawal of Some 2,700 Troops, Police, SC/10411, 14 October 2011. 
Simić, O. (2010). Does the Presence of Women Really Matter? Towards Combating Male Sexual Violence in Peacekeeping Operations, International Peacekeeping, 17(2), 188199.

Spencer, S. (2004). Making Peace: Preventing and Responding to Sexual Exploitation by United Nations Peacekeepers, Journal of Public and International Affairs, (16), 167-181.

Tamil Guardian. (2008, 9 April). UN confirms sex charges against Sri Lankan troops in Haiti child abuse. http://www.tamilguardian.com/article.asp?articleid=1652 (Access: 19 May 2020).

The Secretary-General, (2003, 9 October). Secretary-General's Bulletin, Special measures for protection from sexual exploitation and sexual abuse, at para 1. U.N. Doc. ST/SGB/2003/13.

Vezina, R. (2012). Combating Impunity in Haiti: Why the ICC Should Prosecute Sexual Abuse by UN Peacekeepers, Ave Maria International Law Journal, 1(2), 431-460. 
Culture of Silence: Scrutinising the UN's "Zero Tolerence" Approach to Sexual Exploitation and Abuse in Peace Keeping Operations 